\title{
UTICAJ NACIONALNE KULTURE NA PROCES UPRAVLJANJA ORGANIZACIONIM PROMENAMA
}

\author{
Đurđijana llić \\ Univerzitet odbrane u Beogradu, Vojna akademija \\ Marko Andrejić" \\ Univerzitet odbrane u Beogradu, Vojna akademija \\ Visoka brodarska škola akademskih studija, Beograd \\ Miljojko Janošević \\ Ministarstvo odbrane Republike Srbije, \\ Vojnomedicinska akademija, Beograd \\ Slađana llić \\ Ekonomsko-trgovinska škola, Kruševac
}

straživanjima je utvrđeno da nacionalnu kulturu u Srbiji karakteriše vi-

soka distanca moći, visoko izbegavanje neizvesnosti, visok stepen kolektivizma i dominantne ženske vrednosti (raspodela uloga između rodova). Te karakteristike su u suprotnosti sa karakteristikama nacionalne kulture zapadnih zemalja koje predstavljaju ideal kojem Srbija teži na svom putu ka EU. Uvođenje novih vrednosti u nacionalnu kulturu i upravljanje promenama u organizacionim kulturama preduzeća u Srbiji može dovesti do kontradiktornih smernica u organizacionom i individualnom upravljanju organizacionim promenama i do većih otpora promenama. Interesovanje za uticaj nacionalne kulture i inter-kulturalni menadžment je naglo poraslo sa intenziviranjem globalizacije. Za rezultate ovih istraživanja su vrlo zainteresovane multinacionalne kompanije koje se svakodnevno susreću sa dilemom: kako se prilagoditi lokalnim kulturama i tako povećati efikasnost menadžment prakse u lokalnim jedinicama a istovremeno očuvati jedinstveni sistem menadžmenta i snažnu korporativnu kulturu. Poznavanje uticaja nacionalne kulture na organizacione promene važno je zbog efektivne i efikasne primene poznatih znanja, iskustava i pouka u sprovođenju promena koje nam odgovaraju, ali isto tako i u uspešnom suprotstavljanju „spoljnjem nametanju“ promena koje nisu u našem nacionalnom interesu. Kod donošenja odluka o promenama u nacionalnoj kulturi i krupnim organizacionim promenama treba pratiti i ključne vektore vremena, a ne prolazne nosioce određenih društvenih uloga.

Ključne reči: nacionalna kultura, nacionalni interesi, organizacija, organizacione promene, upravljanje organizacionim promenama

\footnotetext{
* Pukovnik u penziji, sa zadržanim zvanjem redovnog profesora Vojne akademije Univerziteta odbrane u Beogradu.
} 
Qazvoj društva i države podrazumeva razmene i promene. Savremene uslove života i rada karakteriše pojačana kooperacija i integracija među nacijama, formiranje velikih multinacionalnih korporacija koje imaju multikulturnu radnu snagu, ofanzivno osvajanje novih tržišta, novih potrošača, novih izvora sirovina i nove radne snage (jeftine a kvalitetne) i pojačano isključenje upliva države u privredne tokove. Da bi se ovi trendovi održali neophodno je da se sprovode određene promene. Svaka ozbiljna država nastoji da upravlja tim promenama u smeru i ka ciljevima koji odgovaraju njenoj nacionalnoj kulturi, mogućnostima i potrebama. Da bi se adekvatno upravljalo promenama u nacionalnoj kulturi (globalnog i lokalnog karaktera) i kulturama organizacija, neophodno je da donosioci odluka i menadžment poznaju različite nacionalne kulture i kroskulturalni menadžment. Najznačajniji resurs u državi i organizacijama su ljudi, zato je upravljanje ljudskim resursima vrlo važno.

Novi svet biznisa, podrazumeva poslovanje koje će biti konkurentno na duži vremenski period, a kako se govori o rasprostiranju poslovnih aktivnosti van matične zemlje, poznavanje kulture i običaja poslovnih partnera je jedan od bitnih preduslova. Poslovna kultura se gradi na uspešnoj poslovnoj komunikaciji i uspostavljanju kvalitetnih poslovnih veza. [14] Zelja da se poslovni partner upozna pre stupanja u poslovni proces je prisutna u onim zemljama gde se svaki razgovor usmerava ka konkretnoj realizaciji poslovnih aktivnosti, a to je karakteristično za germanske zemlje. Na jugu i jugozapadu Evrope i drugim delovima sveta, važi pravilo da je dobro poznavanje osobe sa kojom se sarađuje osnova za stvaranje poverenja, a onda neminovno sledi i uspeh poslovnog poduhvata. Bez obzira što su zapadni koncepti i standardi inicirali renesansu „pokreta za promene“ u svim poljima objektivne stvarnosti uključujući i nacionalnu i organizacionu kulturu, oni ne smeju svojim zapadnim karakterom da minimiziraju specifičnost naše nacionalne kulture i usmere nas da tuđim očima gledamo našu objektivnu stvarnost. Kosmopolitizam ne isključuje sopstveni identitet već, naprotiv, oslanja se na istinsko poznavanje samoga sebe.

Poznavanje uticaja nacionalne kulture na organizacione promene važno je zbog efektivne i efikasne primene poznatih znanja, iskustava i naučenih lekcija u sprovođenju promena koje nam odgovaraju, ali isto tako i u uspešnom suprotstavljanju „spoljnjem nametanju“ promena koje nisu u našem nacionalnom interesu. Vrlo je važno razumeti uticaj nacionalne kulture na organizacione promene, vrste i proces organizacionih promena kako bi se adekvatno postupalo u istima i obezbedilo usklađeno delovanje i homogeno postupanje svih steikholdera. Neadekvatno postupanje pri uvođenju novih vrednosti u nacionalnu kulturu i upravljanje promenama u organizacionim kulturama preduzeća (organizacija) u Srbiji može dovesti do kontradiktornih smernica u organizacionom i individualnom upravljanju organizacionim promenama, a time i do njihovog sporog odvijanja pa i neuspeha ${ }^{1}$.

Promene u organizaciji se vrše, radi opstanka i razvoja organizacije, preventivno radi sprečavanja dolaska organizacije u nepovoljno stanje ili korektivno kad već nastupi nepovoljno stanje po organizaciju (što treba nastojati da se izbegne). Pri sprovođenju promena u multinacionalnom okruženju neophodno je kombinovati znanja iz oblasti kulture (istorija, tradicija, običaji, religije) sa znanjem iz oblasti ekonomije (privredni sistemi zemlje, način ra-

\footnotetext{
${ }^{1}$ Polazeći od dijalektičkog jedinstva opšteg, posebnog i pojedinačnog, može se tvrditi da sve ono što uopšte vredi za uticaj nacionalne kulture na promene u organizaciji, vredi i za sistem odbrane kao važan državni podsistem.
} 
da organizacija, sistem privrednog zakonodavstva, upravljanje ljudskim resursima), politike (političko uređenje zemlje i način rada Vlade) i sociologije (osnovne društvene norme, raslojavanje društva, potrebe i motivisanost stanovništva). ${ }^{2}$ Ovaj rad ima za cilj da, da na bazi dostupnih teorijskih izvora i praktičnih iskustava, pruži saznanja potrebna donosiocima odluka i poslovnim ljudima za uspešno pregovaranje sa ljudima iz drugih kultura i podneblja u procesu osmišljavanja i sprovođenja organizacionih promena.

\section{Nacionalna kultura}

Reč kultura izvedena je iz reči kult (idol, uzor) i ona artikuliše ciljeve jedne zajednice. Kultura predstavlja sistem društvenih normi i vrednosti kojima se regulišu odnosi u socijalnom siste$\mathrm{mu}^{3}$ i svodi prirodni objektivni zakon obmane u podnošljive okvire. ${ }^{4}$ Uz pomoć kulture mogu se sačuvati stvorene kulturne i druge vrednosti ${ }^{5}$ života i rada, kao i sam život, a kroz zadovoljenje potreba čoveka. Kultura i kvalitet su dve kompatibilne kategorije u socijalnom sistemu, užem i širem. Ti termini su kompleksni i sveobuhvatni. Oni se odnose na sve materijalne i nematerijalne entitete koji su stvoreni radom ili prirodno postoje kao resursi. Misao, govor i rad na osnovu predumišljaja (razmišljanja) je postalo osnova ljudske kulture. Kultura je rezultat različitosti negenetski uslovljene delatnosti pokoljenja ljudi ali, potencijal osvajanja sredine od strane čoveka je genetski uslovljen, između ostalog i na račun kulture. Sledi da je kultura jedan od mnogih faktora globalnog evolucionog procesa. Ne postoji dobra i loša kultura (nekultura). Postoji samo jedinstvena mnogolika kultura koja se predaje negenetski s pokoljenja na pokoljenje, a u njoj se nalaze i delovi koji su opasni za ljude i čovečanstvo. Proces razvića kulture (globalnog istorijskog procesa) jedan je od pojedinačnih procesa globalnog evolucionog procesa biosfere.

Kultura se genetski ne nasleđuje. Kulturu ne nosi biološka populacija, već socijalna organizacija biološke populacije. Kultura je faktor životne sredine koji utiče na ljude. Ona utiče na populaciju svih vrsta, na čoveka i na celu svoju biocenozu. Razviće kulture utiče na reprodukciju ljudskih populacija, dok su druge vrste uslovljene samo prirodno - geografskim faktorima. Čoveka za razliku od drugih živih bića uslovljava kultura sa određenim obeležjima: nacionalnim, klasnim, elitnim. U kulturnim tradicijama socijalne organizacije naroda to su običaji, sistem upravljanja, odnosi među ljudima i zato nametanje tuđe kulture narodu izaziva otpor. Kulturna razmena retko unosu nov kvalitativni sadržaj u živote naroda. ${ }^{6}$ Iskorenjivanje neugodnih kultura u istoriji čovečanstva uvek je praćeno genocidom od strane osvajača: narkotičkim (piće, droga), ekonomskim (privatizovanjem i otimanjem prirodnog bogatstva tako da oni koji ga nemaju žive bolje od onih koji imaju isto), i raznim nametnutim „kulturnim programima“.

\footnotetext{
${ }^{2}$ Saznanja stečena kroz proces transformacije VS (radikalna promena strukture, organizacione kulture, stavova, vrednosti zaposlenih) ukazuju da je neophodno na UnO više izučavati sadržaje vezane za uticaj nacionalne kulture na promene $u$ organizaciji.

${ }^{3}$ Kultura je i umetnost življenja! Poštovanja, davanja, primanja, uvažavanja, pre svega prema porodici i društvu i drugim segmentima života! Kultura nije uštogljenost, već umeće življenja uz samopoštovanje i poštovanje drugih i sveta uopšte. Ne može se biti delimično kulturan. Kulturan čovek je kulturan u svim segmentima života.

${ }^{4}$ Kultura su zajednička i relativno stabilna verovanja, stavovi i vrednosti koji postoje u organizaciji. (Williams, Dobson\&Walters, 1993).

${ }^{5}$ Vrednost: spoj korisnosti i retkosti, u ekonomiji, socijalnom i drugim sistemima.

${ }^{6}$ Indijci i Eskimi i dalje žive kao što su i nekada živeli i odbacuju pokušaj nametanja tuđe kulture.
} 
Pod nacionalnom kulturom podrazumeva se skup pretpostavki, verovanja i vrednosti koje su prihvatili pripadnici jedne nacionalne zajednice i koji bitno određuje njihovo razumevanje sveta i ponašanja u njemu. $U$ kulturnim tradicijama socijalne organizacije naroda to su običaji, sistem upravljanja, odnosi među ljudima. Nacionalna kultura je, generalno, ne samo vrhovni izraz individualnih vrednosti i kolektivnog duha jednog naroda, već i moćno oružje u rukama onih koji znaju da kulturne vrednosti promovišu i štite. Ako imate kulturu imate i tradiciju, ako imate tradiciju imate i naciju, a ako imate naciju imate i državu. Nacionalna kultura je važan faktor koji opredeljuje i individualne vrednosti i ponašanje pojedinca, ali i vrednosti organizacione kulture i ponašanje celokupnih organizacija. Na primer, ukoliko neka nacionalna kultura sadrži vrednosti autoritatizma to znači da će, vrlo verovatno, većina organizacija u toj nacionalnoj zajednici imati centralizovanu strukturu, a lideri tih organizacija autokratski stil upravljanja. Vrednosti nacionalne kulture utiču na sve elemente organizacionog ponašanja: profil motivacije i nagrađivanje zaposlenih, stil vođstva, upravljanje promenama i sl.

U uslovima globalizacije kada nestaju granice između država, kada veliki broj preduzeća (globalna) posluju u zemljama različitih kultura i imaju tzv. multikulturnu radnu snagu, važnost nacionalne kulture dobiće poseban značaj za organizaciono ponašanje. $U$ takvim situacijama dolazi do „mešanja“ kultura što može dovesti do nesporazuma, konflikata, stresa, frustracije, nerazumevanja. „,Sudar" kultura ima i pozitivnu stranu koju čine razmena, obogaćivanje i unapređivanje kulturnog nasleđa. Da bi preduzeće uspešno poslovalo menadžment mora razumeti, prihvatiti i poštovati kulturu drugih nacija i vešto upravljati promenama.

\section{Dimenzije nacionalne kulture}

Pretpostavke, vrednosti i norme nacionalne kulture su u najvećoj meri podsvesnog karaktera. One definišu stavove o prirodi ljudskog karaktera - da li su ljudi po prirodi dobri ili loši, vredni ili lenji, promenljivi ili nepromenljivi. Pretpostavke definišu i odnos ljudi prema prirodi tj. da li ljudi mogu biti u harmoniji sa prirodom i da li mogu ovladati prirodom. Nacionalna kultura definiše i odnose među ljudima: da li su jednaki, da li bi trebalo da budu jednaki sa drugima ili moćniji od drugih, odnos pojedinca i kolektiva. Ljudi ove odnose i pretpostavke ne uvažavaju dovoljno sve dok se ne nađu u kulturi koja se razlikuje od njihove. Tek kada se nađu u drugačijoj kulturi postaju svesni različitosti svojih i tuđih stavova i pretpostavki.

Holandski autor, Geert Hofstede, sa grupom svojih saradnika, krajem 70 - ih godina prošlog veka, izvršio je istraživanja nacionalnih kultura i njihovih dimenzija u 40 svetskih država. U istraživanju je učestvovalo 116.000 ispitanika što je možda najveći broj ispitanika u istoriji istraživanja u menadžmentu. Upitnici su napravljeni na čak 20 svetskih jezika a istraživanje je sprovedeno u filijalama multinacionalne kompanije IBM. Nakon izvršenog anketiranja podaci su obrađeni, naknadno provereni i testirani. U ovom istraživanju učestvovala je i SFRJ. S obzirom na to da je anketiranje obavljeno u Ljubljani, Zagrebu i Beogradu, kasnije raspadom SFRJ, mogli su se izdvojiti pojedinačni rezultati za Sloveniju, Hrvatsku i Srbiju. Hofsted je pomoću svojih saradnika definisao četiri osnovne dimenzije, na osnovu kojih se razlikuju nacionalne kulture u svetu. Dimenzije su dvopolnog karaktera što znači da se svaka nacionalna kultura može po svakoj dimenziji pozicionirati na kontinuumu između dva ekstrema te dimenzije.

Distanca moći je dimenzija nacionalne kulture koja pokazuje „stepen u kojem društvo prihvata činjenicu da je moć u institucijama i organizacijama raspodeljena nejednako“. Distanca 
moći pokazuje stepen u kojem pripadnici jedne nacionalne kulture smatraju normalnim i očekivanim da moć bude neravnomerno raspoređena odnosno da u društvu ima vrlo moćnih pojedinaca i grupa kao i onih koji uopšte nemaju moć. Distanca moći pokazuje stavove onih koji imaju moć ali i onih koji nemaju moć, onih koji su prinuđeni na poslušnost. Visoka distanca moći znači da i jedni i drugi smatraju da je sasvim normalna pojava i prirodno stanje stvari nejednaka distribucija moći u društvu ili organizaciji i da se ova dimenzija niti može niti treba menjati. U ovakvim društvima dolazi do pojave pokreta (socijalni ili politički bunt), a cilj nije ujednačavanje rasporeda moći u društvu, već uvećanje moći onima koji su do juče imali manje moći i obratno. U takvim društvima, smatra se da je preduslov za normalno funkcionisanje nejednakost distribucije moći. U društvima sa visokom distancom moći, kao što je kod nas slučaj, preovladava autoritarna svest, pa je i stepen autoritatizma vrlo visok. Moćniji se smatraju posebnom vrstom ljudi, tako da manje moćni imaju neograničeno ali ničim opravdano poverenje u njihovu sposobnost. Iz toga proizilazi nezreo, infantilan ${ }^{7}$ odnos prema autoritetu. Autoritetima se dozvoljava i ono što „običnim smrtnicima" nije dozvoljeno, ali se zbog toga od njih očekuje da rešavaju sve probleme svojih podanika. Ovaj odnos podseća na odnos nezrele dece prema roditeljima.

U društvima sa visokom distancom moći oni koji je imaju nastoje da bude vrlo primetna i uverljiva. Nepoštovanje zakona i pravila koji važe za sve članove društva tzv. „obične smrtnike" jedan je od osnovnih načina dokazivanja moći od strane onih koji je poseduju. Najmanji znak slabosti ili poraza onoga ko poseduje moć ostali članovi posmatraće kao slabost i zloupotrebiće je tako što će ga odbaciti. Ovo je razlog zbog kog svaki vođa društva sa visokom distancom moći mora stalno dokazivati svoju snagu i moć, tj. mora biti rigidan i održavati distancu između sebe i okoline. ${ }^{8}$

Ovo su prema Hofstedu 20 zemalja sa najvišim stepenom distance moći: Malezija, Gvatemala, Panama, Filipini, Venecuela, Meksiko, Arapske zemlje, Ekvador, Indonezija, Indija, Zapadna Afrika, Jugoslovenske države, Singapur, Hong Kong, Salvador, Turska, Tajland, Istočna Afrika, Peru, Portugal.

Nasuprot tome, društva sa niskom distancom moći prihvataju stav da moć treba što je više moguće ujednačavati među članovima društva. S obzirom na to da je nejednaka distanca moći nepoželjna, sledi negativan stav prema onima koji teže većoj moći od drugih. Ovaj stav je uopšte negativan prema moći pa se o njoj govori kao o nečemu „prljavom“. Predviđa se činjenica da se bez moći ne može izvršiti nikakva promena u društvu ili organizaciji, pa moć u društvu ima ulogu kakvu u prirodi ima sila. Pošto moć u društvu ne može biti ravnomerno raspoređena, razvija se posebna vrsta hipokrizije - moć se smatra nedostojnom, nepoželjnom, dok istovremeno postoje mnogi pojedinci i grupe koje nastoje da ostvare što veću moć. Zbog negativne slike o moći, oni koji je imaju pokušavaju da je prikriju, ponašajući se što sličnije običnim građanima, a podrazumeva se da je potrebno da budu još oprezniji u poštovanju zakona.

Prvih 20 zemalja sa niskim stepenom distance moći su: Austrija, Izrael, Danska, Novi Zeland, Irska, Norveška, Švedska, Finska, Švajcarska, Nemačka, Velika Britanija, Kosta Rika, Australija, Holandija, Kanada, SAD.

\footnotetext{
${ }^{7}$ Infantilnost je kod odrasle osobe ispoljavanje nekih tipično dečjih karakteristika mišljenja, emocionalnog reagovanja ili obrazaca ponašanja. Nezrelost, naivnost, neprilagođenost obrascu očekivanog ponašanja i kao razvojni poremećaj.

${ }^{8}$ Razlog je što je uklanjanje autoriteta vladaoca prilikom uklanjanja pojedinih vladara od strane centara moći jedan od vrlo zastupljenih načina nasilnih prevrata nenasilnim sredstvima.
} 
Izbegavanje neizvesnosti ukazuje na stepen ugroženosti članova društva u neizvesnim, nejasnim ili promenljivim okolnostima. Nacionalne kulture sa visokim stepenom izbegavanja neizvesnosti ne vole promene, neizvesnost i rizik. One teže formalizaciji, standardizaciji i hijerarhiji koje treba da obezbede stabilnost i uređenost. Ljudi vole da sve bude poznato i jasno i da se što manje menjaju. Na promene se ne gleda kao na šansu za unapređenje već kao na pretnju. Kod ovakvih kultura dominantno je verovanje u večitu i krajnju istinu koju obično nameće lider, a predstavlja je kao opšte mišljenje. Stepen tolerancije prema razlikama i različitom mišljenjima je veoma nizak a izražen je visok stepen agresivnosti i anksioznosti.

Individualizam - kolektivizam - Osnovna razlika između individualizma i kolektivizma sastoji se u tome kako se određuje odgovornost za sopstvenu sudbinu. Individualizam podrazumeva da je svaki pojedinac odgovoran za sebe i za svoju najbližu porodicu. Nasuprot tome, kolektivizam podrazumeva da je za sudbinu svakog pojedinca ponaosob odgovoran kolektiv kojem pripada, bez obzira da li je to porodica, preduzeće ili društvo u celini. Individualizam polazi od tzv. voluntarizma, odnosno pretpostavke da postoji „slobodna volja“ ljudi. To znači da postoji verovanje da ljudi svojom slobodnom voljom mogu menjati stvari i aktivno uticati na sopstvenu sudbinu. $U$ individualističkim kulturama razlika koju pojedinac svojim ponašanjem unosi u okolinu je na visokoj ceni.

Kolektivizam podstiče verovanje u determinizam koje može ići i do fatalizma a ništa se ne može izmeniti jer je sve unapred zacrtano. Ne postoji vera u promene, čak se smatra da niko ne može izmeniti ni samog sebe jer čovek kakav se rodi, tako će i umreti. Ljudi svojim postupcima samo „ispunjavaju“ utvrđen plan „viših sila“. Kulture okrenute individualizmu identitet zasnivaju na pojedincu dok se kod kolektivističkih kultura zasniva na socijalnom sistemu (kolektivu). „Narod je uvek u pravu“ je tradicionalno verovanje u večnu nepogrešivost i apsolutni autoritet kolektiva pa zbog toga u ovakvim kulturama uvek mora postojati neki oblik socijalnog sistema. Da bi formirali lični identitet moraju se poistovetiti sa nekim od oblika socijalnog sistema. U kolektivističkim kulturama nema ,ja“ već „mi“, odnosno „ja“ proističe iz „mi“. U koliko se naiđe na ,ja“ to je opet pripadnost nekoj socijalnoj grupi (naciji, klasi, religiji, društvenoj grupi, socijalnom sloju, navijačkim grupama itd.).

Individualizam podrazumeva "labaviju“ društvenu strukturu, u kojoj svako brine za sebe, socijalne veze nisu tako čvrste a porodica je vrlo uska, primarna. Nasuprot tome, u kolektivizmu postoji vrlo snažna socijalna struktura intenzivnih socijalnih odnosa a od pojedinca se očekuje da pored brige o sebi, brine i o porodici koja je obično vrlo široka (gde ce često ubrajaju i zemljaci, saplemenici...) ali i o članovima kolektiva kojem pripada. Suština kolektivizma sadržana je u verovanju da pojedinac ima pravo da očekuje da ga njegov kolektiv zaštiti i vodi računa o njegovim potrebama a za uzvrat je dužan da svom kolektivu bude apsolutno lojalan.

Razlike između individualizma i kolektivizma mogu se uočiti i posmatrajući porodične odnose. Mladi u individualističkim kulturama se veoma rano osamostaljuju, već punoletstvom, jer smatraju da roditelji posle navršenih osamnaest godina nisu dužni da ih izdržavaju. Nasuprot tome, mladi iz kolektivističkih nacionalnih kultura na porodične odnose gledaju „drugim“ očima pa smatraju da je roditeljska dužnost da se brinu o njima pa i da im materijalno pomažu čak i u njihovim zrelim godinama. Oni čak i u četrdesetim godinama dozvoljavaju roditeljima da im se mešaju u lični ili porodični život. Zauzvrat će brinuti o svojim roditeljima kada budu u poznim godinama (primer Srbija i Latinska Amerika).

Tipični predstavnici individualističkih kultura su: SAD, Australija, zemlje zapadne i centralne Evrope, a predstavnici kolektivističkih kultura: zemlje Latinske amerike, bivše Jugoslovenske zemlje, Azijske zemlje. 
„Muške“ nasuprot „ženskim“ vrednostima - Kod kultura u kojima preovlađuju tzv. „muške“ vrednosti cene se postignuća, uspeh, rezultati, agresivnost, kondicija. To su tzv. „činiti“ kulture u kojima se nečija vrednost dokazuje rezultatom ili činjenjem. U korenu „muških“ kultura je pretpostavka o slobodnoj volji čoveka. Dominantne vrednosti su: novac, moć, sve što čini materijalni status, sposobnost. U međuljudskim odnosima se kontrolišu emocije i ostavlja utisak apsolutne sigurnosti, samouverenosti i nezavisnosti od drugih. Ove kulture nazivaju se i materijalističkim a tu spadaju: Japan, Australija, Venecuela, Italija, Švajcarska, Meksiko, Jamajka, Irska, Nemačka. U „ženskim“ nacionalnim kulturama dominiraju „ženske“ vrednosti: međuljudski odnosi, kvalitet života, ravnoteža, sklad, briga o sredini. Cene se tolerancija, nežnost, ljubav, toplina, strast. Ovo su tzv. „biti“ kulture u kojima se vrednosti ljudi dokazuju samim postojanjem i ulogom u socijalnoj mreži. U ovim kulturama prednost se daje uspostavljanju dobrih veza i odnosa sa prirodnim i socijalnim okruženjem u odnosu na materijalni status. Ispoljava se veća tolerancija prema različitom, teži se ravnopravnosti. Emocije se ne skrivaju a komunikacija je sporija, smirenija, opuštenija. Ove kulture se nazivaju i solidarističkim kulturama i tu spadaju: Skandinavske zemlje, kao i zemlje bivše Jugoslavije.

\section{Dimenzije jugoslovenske nacionalne kulture}

$\mathrm{Na}$ osnovu Hofstedovih originalnih istraživanja jugoslovenska nacionalna kultura ima jedinstvenu kombinaciju visoke distance moći, visokog izbegavanja neizvesnosti, kolektivizam i ženske vrednosti.

Jugoslovenska nacionalna kultura (tabela 1), je po svojim kulturnim karakteristikama najbliža kulturama Latinske Amerike (Čile, Meksiko, Venecuela, Kolumbija), a nešto manje zemljama Latinske Evrope (Francuska, Italija, Španija). Latinoameričke kulture su najsličnije jugoslovenskim kulturama, a jedina razlika je ta da su u latinoameričkoj kulturi dominantnije "muške“, dok su kod nas izraženije „ženske“ vrednosti.

Tabela 1 - Dimenzije jugoslovenske nacionalne kulture

\begin{tabular}{|l|c|c|}
\hline \multicolumn{1}{|c|}{ Dimenzije nacionalne kulture } & Indeks & Rang \\
\hline Distanca moći - PDI & $76(11-104)$ & 12 \\
\hline Izbegavanje neizvesnosti - UAI & $88(8-112)$ & 8 \\
\hline Individualizam - IND & $27(6-91)$ & $33-35$ \\
\hline Muške vrednost - MAS & $21(5-95)$ & $48-49$ \\
\hline
\end{tabular}

Sličnost latinoevropske i jugoslovenske kulture ogleda se u dimenzijama distance moći i izbegavanju rizika. Kultura Francuske, Italije i Španije je individualistička i muška, dok je naša nacionalna kultura u velikoj meri kolektivistička i ženska. Sa skandinavskim kulturama takođe imamo i sličnosti i razlika. Sličnost je u prihvatanju ženskih vrednosti a razlika u svim ostalim dimenzijama. Zajednička dimenzija germanskih nacionalnih kultura i naše nacionalne kulture je visoko izbegavanje neizvesnosti a razlika u distanci moći i kolektivizmu. Najveće razlike, po svim dimenzijama, postoje između anglosaksonske i naše nacionalne kulture. Najmanja razlika je kod dimenzije „muške - ženske“ vrednosti. 
Preciznije upoređenje indeksa po svim dimenzijama nacionalnih kultura bivše Jugoslavije i relevantnih grupa nacionalnih kultura prikazano je u sledećoj tabeli (tabela br. 2). Indeksi za grupe nacionalnih kultura su izračunati kao prosek indeksa nacionalnih kultura označenih u zaglavlju tabele.

Tabela 2 - Razlike između nacionalne kulture Jugoslavije i relevantnih zemalja

\begin{tabular}{|l|c|c|c|c|c|c|}
\cline { 2 - 7 } \multicolumn{1}{c|}{} & $\begin{array}{c}\text { JugosI. } \\
\text { kultura }\end{array}$ & $\begin{array}{c}\text { Anglosk. } \\
\text { kulture - } \\
\text { V. Britanija, } \\
\text { SAD }\end{array}$ & $\begin{array}{c}\text { Germanske } \\
\text { kulture } \\
\text { Nemačka, } \\
\text { Austrija }\end{array}$ & $\begin{array}{c}\text { Skand. } \\
\text { kulture - } \\
\text { Svedska, } \\
\text { Norveška }\end{array}$ & $\begin{array}{c}\text { Latino - } \\
\text { evropske } \\
\text { kulture - } \\
\text { Francuska, } \\
\text { Italija }\end{array}$ & $\begin{array}{c}\text { Latino - } \\
\text { američke } \\
\text { kulture - } \\
\text { Meksiko, } \\
\text { Venecuela }\end{array}$ \\
\hline $\begin{array}{l}\text { Distanca moći } \\
\text { PDI }\end{array}$ & 76 & 37,5 & 22,5 & 31 & 59 & 81 \\
\hline $\begin{array}{l}\text { Izbegavanje } \\
\text { neizvesnosti UAI }\end{array}$ & 88 & 40,5 & 67,5 & 39,5 & 80,5 & 79 \\
\hline $\begin{array}{l}\text { Individualizam } \\
\text { IND }\end{array}$ & 27 & 90 & 61 & 70 & 73,5 & 21 \\
\hline $\begin{array}{l}\text { Muške vrednosti } \\
\text { MAS }\end{array}$ & 21 & 64 & 72,5 & 6,5 & 56,5 & 71 \\
\hline
\end{tabular}

\section{Uticaj nacionalne kulture na organizacionu strukturu}

Uticaj nacionalne kulture na organizacionu strukturu najviše je istraživao Hofsted, mada su i drugi autori istraživali njen uticaj na strukturisanje organizacija koristeći druge dimenzije nacionalne kulture. Hofsted je koncept organizacionog strukturisanja preuzeo od autora Aston studije, koji su ga podelili na dve osnovne dimenzije: koncentracija autoriteta (ko o čemu treba da odlučuje) i strukturisanje aktivnosti (ko i šta radi u organizaciji). Pitanje definisanja strukture autoriteta rešava se određenim stepenom centralizacije ili decentralizacije donošenja odluka a pitanje definisanja strukture izvršnih zadataka specijalizacijom, formalizacijom i standardizacijom u organizaciji.

U nacionalnim kulturama sa visokom distancom moći, organizacije imaju tendenciju da budu centralizovane više nego organizacije u kulturama sa nižom distancom moći, ukoliko su ostali faktori jednaki. U svakoj kulturi će velika preduzeća biti više decentralizovana u odnosu na mala, ali će dva preduzeća uporedive veličine biti u različitom stepenu decentralizovana u različitim nacionalnim kulturama.

$\mathrm{Na}$ osnovu analize dimenzija nacionalne kulture i dimenzije organizacione strukture Hofsted je postavio sledeće hipoteze o odnosu nacionalne kulture i organizacione strukture:

1. Što je veća distanca moći u nacionalnoj kulturi, to je viši stepen centralizacije autoriteta i obrnuto.

2. Što je viši nivo izbegavanja neizvesnosti u nacionalnoj kulturi, viši je i nivo formalizacije uloga u strukturisanju aktivnosti i obrnuto. 
Visok stepen centralizacije odlučivanja i formalizacije uloga i sklonost organizacionom modelu pune birokratije nalazimo u nacionalnim kulturama koje imaju visoku distancu moći i visoko izbegavanje neizvesnosti kao što je slučaj u Srbiji i drugim bivšim zemljama Jugoslavije, Latinoevropskim i Latinoameričkim zemljama. Tendenciju primene visokog stepena formalizacije ali nizak stepen centralizacije u strukturisanju kao i model profesionalne birokratije nalazimo u kulturama sa niskom distancom moći ali visokim izbegavanjem neizvesnosti gde se ubrajaju germanske nacionalne kulture. Sklonost adhokratiji kao modelu organizacije sa niskom centralizacijom i formalizacijom imaju kulture sa niskom distancom moći i niskim izbegavanjem neizvesnosti, a to je slučaj anglosaksonskih i skandinavskih zemalja. Visoka distanca moći ali nisko izbegavanje neizvesnosti u dalekoistočnim kulturama, podrazumeva korišćenje jednostavnog modela jer on ima visok stepen centralizacije ali nizak stepen formalizacije strukture.

Hofstede je utvrdio tri različite metafore organizacije (mašine, piramide i tržišta) koje je povezao sa tri grupe nacionalnih kultura. Razlika je prema nivou centralizacije autoriteta i formalizacije uloga, zbog čega su povezane sa klasifikacijom nacionalnih kultura i klasifikacijom organizacionih modela (slika 1).

\begin{tabular}{|c|c|c|c|}
\hline \multicolumn{4}{|c|}{ Distanca moći } \\
\hline \multirow{4}{*}{\multicolumn{2}{|c|}{ 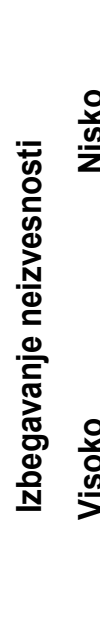 }} & $\begin{array}{c}\text { Metafora: tržište } \\
\text { Organizacioni model: adhakratija } \\
\text { Organizaciona struktura: } \\
\text { - niska centralizacija, } \\
\text { - niska formalizacija } \\
\text { VELIKA BRITANIJA }\end{array}$ & $\begin{array}{c}\text { Metafora: piramida } \\
\text { Organizacioni model: jednostavan } \\
\text { Organizaciona struktura: } \\
\text { - visoka centralizacija, } \\
\text { - niska formalizacija } \\
\text { FRANCUSKA }\end{array}$ \\
\hline & & $\begin{array}{c}\text { Metafora: mašina } \\
\text { Organizacioni model: } \\
\text { - profesionalna birokratija } \\
\text { Organizaciona struktura: } \\
\text { - niska centralizacija, } \\
\text { - visoka formalizacija }\end{array}$ & $\begin{array}{c}\text { Metafora: piramida } \\
\text { Organizacioni model: puna birokratija } \\
\text { Organizaciona struktura: } \\
\text { - visoka centralizacija, } \\
\text { - visoka formalizacija }\end{array}$ \\
\hline & & NEMAČKA & KINA \\
\hline & & Niska & Visoka \\
\hline
\end{tabular}

Slika 1 - Uloga nacionalne kulture u izboru strategije promena u organizacijama Izvor: N. Janićijević, Uloga nacionalne kulture u izboru strategije promena u organizacijama

\section{Promene u korporativnoj i organizacionoj kulturi u Srbiji}

Istraživanja korporativnog upravljanja ukazuju na uticaj privatizacije na promene u načinu upravljanja. U Srbiji i dalje postoje javna preduzeća u kojima se upravlja na nasleđeni socijalističko - samoupravni način zasnovan na državnoj (javnoj) svojini, snažnom političkom uplivu i isplati zarada kao osnovnom motivu poslovanja. Kod privatizovanih preduzeća 
problem kulture i tradicije koče neophodne promene jer ljudi teško menjaju navike stečene u ranijem sistemu upravljanja. Upravljanje ljudskim resursima je, takođe, zastarelo: ne gaji se individualna inicijativa, izražena je razdvojenost menadžerske strukture od zaposlenih, a razvoj se ograničava uglavnom na top - menadžere. Redovne zarade su definisane prema radnom mestu, a ne prema produktivnosti zaposlenih, tako da sistem stimulacija praktično ne postoji ili funkcioniše samo formalno. Poslodavci teže većoj produktivnosti i višem kvalitetu poslovanja, a zaposleni žele i dobre zarade i zadovoljstvo ukupnim uslovima poslovanja, što dovodi do određenih sukoba i otpora od strane zaposlenih.

Strane korporacije koje su postale većinski vlasnici pojedinih preduzeća (organizacija) u Srbiji susreću se sa problemom ugradnje novih elemenata organizacione kulture u kojima se promovišu drugačije vrednosti od postojećih u našoj nacionalnoj kulturi. Neke od domaćih organizacija u privatnom vlasništvu uspele su da izgrade organizacionu kulturu koja promoviše drugačije vrednosti organizacije i podiže konkurentnost organizacije na domaćem i stranom tržištu. Novi načini poslovanja povećali su, u većini slučajeva, produktivnost i ekonomičnost poslovanja, ali ne i emocionalno zadovoljstvo zaposlenih. [13] Sa druge strane, pokazalo se da podizanje sistema kvaliteta ne pokreće za sobom automatski i organizacione promene. Istraživanje ekonomskog instituta u Srbiji je pokazalo da uvođenje sertifikata ISO 9001:2000 nije dovoljan pokretač promena u organizaciji. Jedno od objašnjenja ovakve pojave je da se sertifikati uvode samo formalno i stoga bez stvarnog uticaja na funkcionisanje organizacije.

\section{Teorijska osnova upravljanja promenama}

Upravljanje promenama u organizacijama zahteva kombinovanje dostignuća teorije i operativne praske. Teorija upravljanja promenama obuhvata više različitih i međusobno kompatibilnih pristupa. Najpoznatiji pristupi su: organizacioni razvoj (Organizational Development); strateške promene organizacije ili organizaciona transformacija; institucionalna teorija promena; propadanje (Decline); smanjivanje (Downsizing); zaokret organizacije (Turnaround); životni ciklus organizacije (Organizational Life Cycles); promene kroz improvizaciju; promene u uslovima neizvesnosti; logički inkrementalizam; teorija populacione ekologije (Population Ecology); upravljanje ukupnim kvalitetom (Total Quality Management - TQM); reinžinjering poslovnih procesa ${ }^{9}$ (Business Process Reengineering - BPR); organizaciono učenje i upravljanje znanjem.

Upravljanje promenama postepeno se usmerava ka sledećim perspektivama: organizacioni razvoj, organizacione transformacije (strateške promene organizacije, teorija institucionalnih promena, propadanje, smanjivanje, zaokret organizacije, životni ciklus organizacije), organizacione adaptacije (promene kroz improvizaciju, promene u uslovima neizvesnosti, logički inkrementalizam), procesni pristup kvalitetu i poslovnim procesima (upravljanje ukupnim kvalitetom, reinžinjering poslovnih procesa), organizaciono učenje i upravljanje znanjem.

\footnotetext{
${ }^{9}$ Svi procesi bi trebalo da budu usaglašeni sa ciljevima organizacije i projektovani za stvaranje dodate vrednosti, s obzirom na oblast delovanja i kompleksnost organizacije. Efektivnost i efikasnost procesa se ocenjuje internim i eksternim procesima preispitivanja.
} 
Okruženje je jedan od najznačajnijih i najuticajnijih faktora koji utiču na promene u organizacijama. ${ }^{10}$ Okruženje proizvodi promene. Turbulencija okruženja vremenom je sve veća. Preduzeće je primorano da se prilagođava faktorima i zahtevima okruženja. Sposobnost za promene i fleksibilnost su najznačajnija obeležja savremenog preduzeća.

Fleksibilnost organizacije može biti (J. Atkins):

- funkcionalna (sposobnost prebacivanja zaposlenih sa jednih poslova na druge);

- numerička (omogućava uspešno obavljanje poslova sa manjim brojem stalno zaposlenih);

- finansijska (sposobnost brzog prilagođavanja troškova i zarada tržišnim uslovima).

Proces promene predstavlja prelaz iz postojećeg u neko buduće stanje organizacije (slika 2).

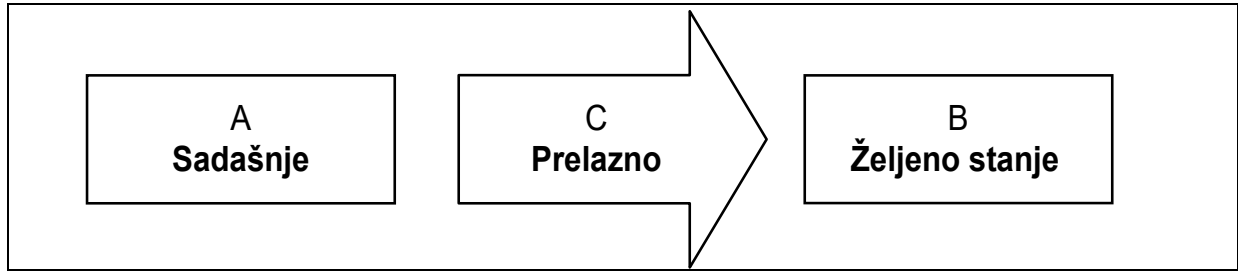

Slika 2 - Proces organizacione promene

Prelazno stanje je najkritičniji period jer je organizacija „u vakumu“. Neophodno je objektivno i egzaktno utvrditi organizacione parametre pre i posle promena. Vrlo je važno utvrditi objektivnu sliku organizacije koja se menja. Ona ne sme biti rezultat želja ili emocija pojedinaca ili grupa. Uspeh promene ne može se jednostavno i brzo utvrditi i izmeriti. Promena se smatra uspešnom ako su ispunjeni sledeći uslovi:

- ostvaren prelaz organizacije iz postojećeg u željeno stanje;

- novo stanje daje rezultate;

- prelaz ostvaren bez većih štetnih posledica i troškova;

- novo stanje ne izaziva značajne posledice za zaposlene u preduzeću.

Za uspešno sprovođenje promene bitan je pristup i način sprovođenja promene. Pristup treba biti primeren postojećim uslovima u datoj situaciji. Neprimeren način sprovođenja promene može da degradira sve prethodne faze i aktivnosti i svaku promenu učini neuspešnom. Promene izazivaju posledice na zaposlene i njihove međusobne odnose. Retke su promene bez (pozitivnih i negativnih) posledica. Svaka promena deluje na pojedince, remeti i menja red stvari, pozicije, odnose i interakcije.

\footnotetext{
${ }^{10} \mathrm{U}$ vreme velikog rasta kompanija tokom 90 - ih godina forsirao se egocentrični pristup rukovođenju, pravljenju lidera koji su i medijske zvezde. To možda i ne bi bio toliki problem da se nije prenelo na niže nivoe, i to na način da su se podređeni borili za podršku šefa tako što su jedan drugog saplitali i težili da budu klonovi nadređenog. Inače, to je čest fenomen u kompanijama. Na primer, imate diktatorski nastrojenog direktora čiji podređeni isti pristup gaje prema svojim podređenima, samo da bi pokazali da prate isti pristup kao i "mudro rukovodstvo". Stara priča o idealnom menadžeru ponovo se javlja, ali i obara, jer je to jedino realno. Ako on slučajno i postoji, sigurno nije u vašoj firmi. Dakle i organizaciona kultura jedna je od stvari koje se moraju menjati ako želite uspeh. Organizaciona kultura se menja ponekad i bez utvrđenih novih ciljeva samo iz razloga jer je došlo do dolaska „novog vođe”. Nesaglasnost između kulturne tradicije kompanije i dominantnih vrednosti „novog vođe" koji dolazi kao naslednik često je uzrok mogućeg poslovnog posrtanja kompanija. Zato je nasleđivanje ili zamena upravljačkog tima jedno od ključnih pitanja upravljanja organizacionom kulturom. U kompanijama sa razvijenom kulturom ovo pitanje se rešava strategijskim pristupom u razvoju kadrova i razvoju karijere.
} 


\section{Proces organizacionih promena}

Prema K. Levinu svako ponašanje u organizaciji rezultat je ravnoteže između pokretačkih snaga i snaga otpora. Pokretačke snage vuku ka promenama, a snage otpora zadržavaju promene i održavaju postojeće stanje. Ako su snage otpora dominantne one mogu sprečiti promene, iako je organizacija u krizi. Osnovni cilj promena je, prema K. Levinu, najpre uklanjanje ili slabljenje snaga otpora, pa tek onda sledi jačanje aktivnosti pokretačkih snaga u organizaciji.

Proces organizacionih promena se realizuje kroz sledeće faze:

- odmrzavanje (priprema za promene);

- menjanje (pomeranje od starog ka novom);

- zamrzavanje (stabilizovanje novog stanja).

Odmrzavanje obuhvata skup aktivnosti koje su suštinski priprema za promene. Pojedinci, grupe i organizacija uviđaju i prihvataju nužnost promena. Ovo je faza savladavanja otpora prema promenama i napuštanja postojećih ideja, navika i metoda rada. Proces odvikavanja od postojećeg je znatno teži i duži od usvajanja novih navika pa je zato nužna pomoć menadžera.

Menjanje označava promenu stanja i može otpočeti tek kada se u potpunosti obavi faza odmrzavanja. Označava prihvatanje i usvajanje novih stavova i vrednosti. [12] Predstavlja novo ponašanje zaposlenih u odnosu na strukturu, procese, kulturu i može se obavljati uz pomoć agenta ili tima za promene.

Zamrzavanje predstavlja stabilizovanje organizacije na novom stanju uz novo ponašanje, norme, pravila i procedure. Ova faza omogućava funkcionisanje preduzeća na novim osnovama i sa novim ciljevima. Da bi bile u potpunosti prihvaćene promene se integrišu u svakodnevno i rutinsko ponašanje zaposlenih.

Proces organizacionih promena podrazumeva: identifikovanje i definisanje problema funkcionisanja; uočavanje potreba za promenama; prihvatanje odluke o promenama; generisanje ideja o sprovođenju promena; kreativnost i inovacije; osmišljavanje i neposredno sprovođenje promena.

\section{Vrste organizacionih promena}

Organizacione promene u preduzeću su različitog trajanja i obima i mogu biti usmerene na promenu tehnologije, promenu delatnosti, strukturne i sistemske promene i promene ljudi. [10] Promene nisu izolovane ${ }^{11}$ jer jedna vrsta promena produkuje ostale organizacione promene. U osnovi odnose se na: promene organizacione strukture, promene tehnologije delatnosti i promene zaposlenih.

Promene organizacionih struktura predstavljaju dominantne promene u preduzeću i obuhvataju promenu celine i delova. Promene strukture su posledica rasta i razvoja preduzeća, kao i organizacionih faktora. Obim i dubina promena zavise od toga da li se radi o reorganizaciji ili organizacionoj transformaciji. Reorganizacija je promena čiji je cilj

\footnotetext{
${ }^{11}$ Sve je deo celine i celina delova, sve je deo igre i igra delova, sve je organizacija - ostalo su samo pojedinci.
} 
prilagođavanje organizacije preduzeća promenama i zahtevima okruženja. Transformacija je promena koja podrazumeva radikalnu promenu strukture, organizacione kulture, stavova i vrednosti zaposlenih.

U savremenoj praksi, najčešći razlozi za promene su: fuzije, akvizicije, promene top menadžmenta i dr. Tokom promena uspostavljaju se novi oblici organizacionih struktura i novi tipovi organizacija: organska, slobodno plivajuća, inovativna, informaciono bazirana (karakteriše preduzeća u 21. veku), simbiotička (ravnoteža i simbioza svih uticajnih faktora), metaonik (zasnovana na promeni sistema vrednosti), atomizirana i fleksibilna (atomizirana oslobađa kreativnost pojedinca) i plitke i niske organizacije zasnovane na savremenim tehnologijama i informatici.

Raniji „raspon kontrole“ zamenjuje se „rasponom komunikacija“. Obrazuju se male jedinice osnovane za izvršavanje zadataka i procesa, organizacije zasnovane na procesi$\mathrm{ma}^{12}$ umesto na funkcijama. Javljaju se kao "ad hoc" strukture, kao zajedničko obeležje za sve vrste fleksibilnih organizacija.

Tehnološke promene su zasnovane na većoj primeni tehnoloških dostignuća, posebno na većoj primeni telekomunikaciono - informacionih tehnologija. Označavaju promene proizvodne tehnologije, postupaka i procesa. Ove promene rezultiraju jeftinijom i masovnijom proizvodnjom a njihov cilj je povećanje funkcionalnosti i učinka. Informaciona tehnologija stvara podloge za brzo i efikasno poslovno odlučivanje. Računarska podrška je postala nezamenljiva, naročito u praćenju procesa, ažurnosti i tačnosti. Nova tehnologija zahteva od zaposlenih nove veštine i znanja. Ona omogućuje oslobađanje od rutinskih poslova, ostavljajući prostor za kreativne aktivnosti. Njihovom primenom smanjuje se potreba za menadžmentom srednjeg nivoa (njihove funkcije preuzima informaciona tehnologija). Automatizovana obrada i distribucija podataka, kao i virtuelne organizacije podstiču decentralizaciju i stil rukovođenja „bez šefa“ (no boss) i omogućavaju ažurno odlučivanje i praćenje radnih i tehnoloških procesa na svim organizacionim nivoima, u bilo koje vreme i na bilo kom mestu.

Promene zaposlenih se vrše u situacijama kada su zaposleni uzrok teškoća. Promena zaposlenih obuhvata promene u vrednostima, veštinama i stavovima zaposlenih i normama ponašanja zaposlenih i menadžera [8], kao pojedinca i u okviru grupe. ${ }^{13} \mathrm{U}$ procesu promena zaposleni moraju da nauče kako da koriste nove tehnologije i znanja ili kako da efikasno rade u timovima. Motivisanost je važan faktor promena. U osnovi organizacionih promena koje se odnose na zaposlene postoje dva pristupa: jedan se odnosi na proces obrazovanja, usavršavanja i treninga postojećih zaposlenih, a drugi na prijem novih zaposlenih.

\footnotetext{
${ }^{12}$ Tradicionalni način posmatranja organizacija je kroz njihovu vertikalnu dimenziju - uvidom u njihovu organizacionu šemu. Na ovaj način stiče se uvid u efektivnost organizacije tj. da li ona radi prave stvari ili, drugačije rečeno, da li je rukovodstvo donelo pravilne odluke o tome šta treba raditi. Međutim, organizacije su sistemi koji se sastoje od procesa kojima se ulazi pretvaraju u izlaze. Rezultati se postižu (ili ne postižu) horizontalno (krosfunkcionalno), a ne hijerarhijski. Stoga, svaka organizacija pored vertikalne mora obratiti pažnju i na horizontalnu dimenziju - mora ono što radi raditi na pravi način tj. efikasno. Svaka odluka koju menadžer donese i svaka operacija koju radnik izvrši utiče pozitivno ili negativno na kvalitet. Zbog toga, da bi proizvele robu ili usluge koje zadovoljavaju i prevazilaze očekivanja korisnika, organizacije moraju dobro razumeti uticaj celog sistema na kvalitet. Postojanje diskontinuiteta između različitih nivoa rukovođenja i međufunkcijskih diskontinuiteta slabi strukturu organizacije, stvarajući niz izolovanih operativnih ostrvaca. Veliki broj sjajnih prilika za unapređenje poslovanja organizacija nalazi se, upravo, između ovih operativnih ostrvaca i ogleda se, prvenstveno, u uspostavljanju bolje komunikacije među njima.

${ }^{13}$ Organizaciona kultura.
} 
S obzirom na različit organizacioni status zaposlenih postoje različiti modaliteti promena:

- ciklično obrazovanje zaposlenih putem kraćih kurseva;

- prijem novih menadžera ukoliko postojeći ne poseduju potrebne veštine i znanja;

- srednji menadžeri sve manje prenose informacije, naloge i odluke, a sve više ugovaraju poslove sa zaposlenima u malim poslovnim jedinicama. Sve više postaju „brokeri“ između kompanije i zaposlenih.

Organizacione promene, po obimu, mogu biti parcijalne i radikalne. Mogu obuhvatiti nivo grupe, tima, odeljenja, pogona ili preduzeća u celini, odnosno mikro i makro nivo. Promene mogu biti postepene i kontinualne ${ }^{14}$, ali i radikalne i povremene. Organizacije se adaptiraju na spoljne i unutrašnje okruženje postepenim i parcijalnim promenama. Parcijalnim organizacionim merama rešavaju se manje krize i zastoji. Postepene promene predstavljaju promene prvog reda. One su blage i plitke. Vrše poboljšanja i parcijalne promene u organizacionoj strukturi, tehnološkim procesima, poslovnim procesima i zaposlenima. Radikalne promene su suštinske i dubinske, one stvaraju novu strukturi i prekidaju kontinuitet postojeće organizacije. Radikalnim promenama se menjaju koncepcija i strategija organizacije. Radikalne promene se sprovode u kriznim periodima kad organizacija bude iznenađena nastupljenim stanjem.

\section{Otpori organizacionim promenama}

Stalna i prateća pojava svih promena jeste pružanje otpora zaposlenih tim promenama. Sprovođenje velikih organizacionih promena produkuje stresno stanje za zaposlene i izaziva otpore zaposlenih. Stanje posle uvođenja promena u preduzeću uglavnom je nestabilno i izaziva osećaj i klimu nesigurnosti. Problemi sa kojima se suočavaju preduzeća pristupajući svakoj većoj organizacionoj promeni su:

- odupiranje i otpor svakoj promeni jer ona predstavlja „nepoznato“,

- strah od gubitka lične pozicije, moći i uticaja,

- stav i mišljenje da je postojeći način rada bolji i da ga ne treba menjati.

Najveće otpore izazivaju promene koje se odnose na ljude. Pridobijanje stava zaposlenih da su za promenu jedan je od najvažnijih zadataka menadžmenta u ukupnom poslu upravljanja organizacionim promenama. Daft grupiše prepreke za sprovođenje organizacionih promena u dve grupe:

- organizacione - fokusiraju se na troškove sprovođenja promena, stepen rizika, nedostatak koordinacije, nekompetentnost sistema i sl.

- personalne - koje se odnose na nesigurnost i strah zaposlenih od promena.

Kao osnovni izvor otpora promenama navode se: [7]

- nesigurnost - ona se uvek javlja u situacijama kada čovek ima šta da izgubi;

- mogući socijalni gubici - svako organizaciono rešenje stvara određenu novu klimu i socijalne odnose u preduzeću;

- ekonomski gubici i štete - javljaju se kod onih pojedinaca koji su zbog promena ostali bez posla ili su premešteni na manje atraktivno ili plaćeno radno mesto;

\footnotetext{
${ }^{14}$ Sve se menja samo su promene stalne.
} 
- neznanje i nespremnost za rad na sebi (smetnje) - javljaju se kao posledica zahteva za dodatnim znanjima, obukom i učenjem;

- gubljenje kontrole - kada promena bude sprovedena zaposleni neće imati kontrolu nad nekim poslovima i resursima preduzeća koje su do tada imali;

- nepredvidive posledice - one se odnose na one delove organizacije i zaposlene koji nisu direktno već indirektno izloženi posledicama promena.

- udružena opozicija - grupa ljudi (može biti spontana ili vođena) pogođena promenama koja se povezuje da bi ojačala otpor budućoj promeni i njenom sprovođenju.

- strah od gubitka uticaja ${ }^{15}$ - predstavlja značajan izvor otpora, kako pojedinca, tako i grupa, odeljenja.

Da bi se smanjio otpor zaposlenih prema promenama menadžment mora pronaći mehanizme za redukovanje otpora. Najčešće metode su:

- izbegavanje iznenađenja - ako se zaposlenima ostavi dovoljno vremena da se upoznaju sa promenama oni će pružiti manji otpor, bez obzira na posledice;

- podsticanje zaposlenih da razumeju promene - Ovo rade menadžeri i rukovodioci. Kada je zaposleni svestan da promenom neće lično ništa izgubiti on će podržati promenu.

- stvaranje uslova za sprovođenje promena - Ako se menadžment u celini zalaže za promene i to ne zbog samih promena, već zbog unapređenja efikasnosti poslovanja i unapređenja pozicije organizacije, to predstavlja značajan podsticaj saradnicima i zaposlenima da prihvate buduće promene.

- probne promene - Za vreme probnog perioda zaposleni se suočavaju sa promenom i na nju navikavaju pre nego što je doneta konačna odluka.

Zaposleni treba da budu informisani o promenama. Participacija zaposlenih u odlučivanju o promenama često je efikasan metod otklanjanja njihovih otpora promenama. Organizacione promene bez kojih je nemoguće buduće funkcionisanje preduzeća, kao nužne i neophodne - imaće podršku većine zaposlenih. Rukovodilac koji sprovodi promene obavezno treba da o njima konsultuje zaposlene i saradnike, čak i putem neobavezne rasprave. Izgradnja poverenja koje menadžeri i rukovodioci uživaju kod saradnika predstavljaju izuzetno značajan faktor podrške promenama. Otpor promenama se prevladava u više faza (Daft):

- izjednačavanje sa potrebama i ciljevima korisnika,

- komunikacija i obrazovanje,

- participacija i uključivanje zaposlenih,

- prisila i prinuda (ukoliko nijedan prethodni način nije dao rezultat).

Ljudi prihvataju promene, uglavnom na tri načina:

- popuštanje - deklarativna saglasnost u kojoj nema verovanja pojedinca u ispravnost odluke o budućoj promeni.

- identifikacija - postoji saglasnost zaposlenih za promenu, veruje se da je promena korisna i da je rukovodilac upravu.

- unutrašnje zadovoljstvo - uradi to jer je vredno to uraditi. Pojedinac prihvata odluku jer je u skladu sa njegovim pristupom.

Sprovođenje organizacionih promena u preduzeću sastoji se od nekoliko faza (slika 3):

\footnotetext{
${ }^{15}$ Često se za nove tehnologije vezuju strahovi koji primarno predstavljaju nerazumevanje, bespomoćnost i odbacivanje strukturnih pomeranja informatičkog društva. Sve to je posledica intenzivnog društvenog razvoja koji životna iskustva i mukom stečene kvalifikacije preko noći devalviraju.
} 


\begin{tabular}{|c|c|c|}
\hline Faza planiranja & Faza upravljanja & Faza stabilizacije \\
\hline $\begin{array}{l}\text { - Stvoriti potrebu } \\
\text { - Odrediti buduće stanje } \\
\text { - Pripremiti se za } \\
\text { promenu }\end{array}$ & $\begin{array}{l}\text { - Odvojiti se od } \\
\text { postojeće prakse } \\
\text { - Organizovati timove } \\
\text { menadžera za kreiranje } \\
\text { promene } \\
\text { - Uključiti članove } \\
\text { organizacije u proces } \\
\text { - Koristiti raznovrsne } \\
\text { metode } \\
\text { - Pružiti povratnu } \\
\text { informaciju } \\
\text { - Stvoriti simbole }\end{array}$ & $\begin{array}{l}\text { - Koristiti sistem } \\
\text { nagrađivanja } \\
\text { - Razmestiti „,̌̌uvare“ } \\
\text { novog načina rada }\end{array}$ \\
\hline
\end{tabular}

Slika 3 - Faze organizacionih promena

Svaka značajna organizaciona promena u preduzeću suočava se sa tri osnovna problema i prepreke:

- Otpor od strane zaposlenih koje ta promena pogađa. Rešava se motivisanjem.

- Otežana organizaciona kontrola. Rešava se u procesu upravljanja promenama. Kontrola i nadzor moraju biti stalno prisutni.

- Gubitak vlasti, moći i uticaja. Rešava se politikom dinamike i sprovođenja promena, tako da "centri moći" podrže promene.

Problem kod uvođenja promena dolaze i od onih koji promene iniciraju (vlasnici) jer, većina ljudi formalno hoće promene ali ih u suštini ne žele. Oni racionalno hoće ali emocionalno neće. Nemoguće je, međutim, sprovoditi promene a da su svi zadovoljni. Potrebno je pojasniti ljudima najjednostavnije stvari - šta svako od njih lično dobija promenama u kompaniji i pojasniti šta promene znače za njihove živote i za organizaciju kao celinu.

\section{Naučene lekcije vezane za menadžment promenama}

Sistematizovano iskustvo vezano za menadžment promenama može pomoći i upravljačima organizacionih promena i onima na koje se promene odnose. Neke od korisnih preporuka za uspešno sprovođenje organizacionih promena jesu:

- Potrebno je vreme da se ljudi prilagode promenama.

- Ljudima pomoći da znaju da su njihove reakcije i emocije normalne.

- Proces tranzicije može biti kontrolisan i upravljan.

- Vremenski zaostatak (time lag) između objavljivanja promena i reakcije na njih treba biti optimalan.

- Ljudi mogu biti u isto vreme u različitim fazama procesa lične tranzicije i da traže drugačiju reakciju menadžmenta.

- Menadžeri prolaze kroz tranziciju pre svojih zaposlenih.

- Proces tranzicije je neizbežan.

Svaki pojedinac se, manje ili više opire promenama jer one unose određenu dozu neizvesnosti, konflikta i rizika. Razloge koje pri tome iznalaze su brojni (slika 4). 


\section{Reasons Not To Change}

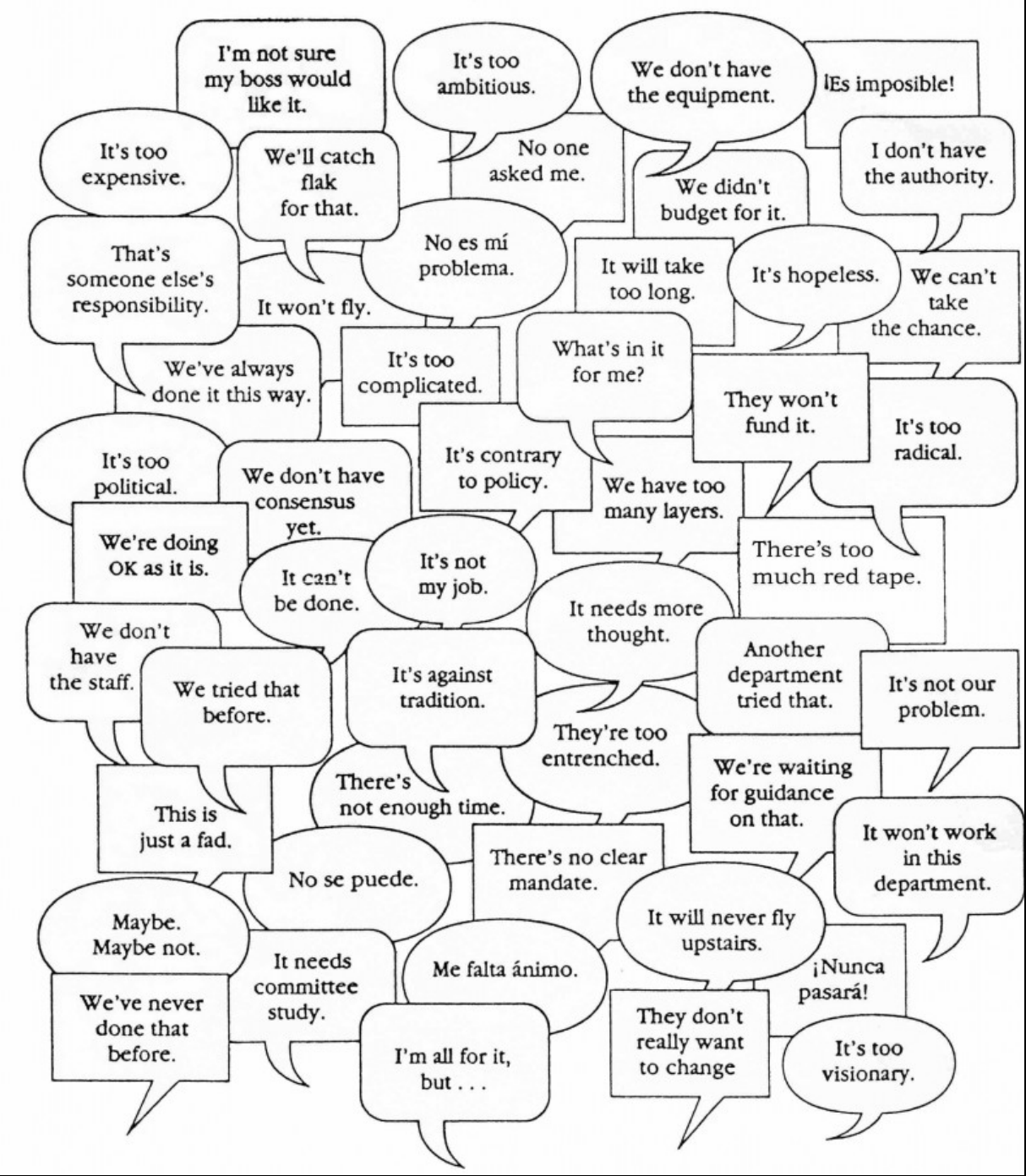

Slika 4 - Razlozi kojima pojedinci opravdavaju otpor organizacionim promenama ${ }^{16}$

https://www.google.com/search?q=50+reasons+not+to+change\&rlz=1C1GGRV enRS751RS751\&tbm=isch\&source=iu\&ic tx=1\&fir=ycUec0Kcqlk8oM\%253A\%252CdysFr6f2iOFckM\%252C_\&vet=1\&usg=Al4kRULMj6SS5asUn4YmsnKGHjcfvHgg \&sa=X\&ved=2ahUKEwjwi Gag8vhAhVCI4sKHQ2WCRwQ9QEwAXoECAkQBg\#imgrc=m rMZrOYXWK25M:\&vet=1 
Da bi se promene uspešno sprovele neophodno je da se primene adekvatne strategije savladavanja otpora promenama (slika 5).

\begin{tabular}{|c|c|c|c|c|}
\hline \multicolumn{5}{|c|}{ STRATEGIJE SAVLADAVANJA OTPORA } \\
\hline & $\begin{array}{c}\text { Strategija } \\
\text { pomaganja }\end{array}$ & $\begin{array}{c}\text { Strategija } \\
\text { informisanja }\end{array}$ & $\begin{array}{c}\text { Kognitivna } \\
\text { strategija }\end{array}$ & $\begin{array}{l}\text { Politička } \\
\text { strategija }\end{array}$ \\
\hline Sadržaj & $\begin{array}{c}\text { Trening i obuka, } \\
\text { emocionalna i } \\
\text { tehnička } \\
\text { podrška u } \\
\text { promeni } \\
\text { ponašanja } \\
\end{array}$ & $\begin{array}{c}\text { Pružanje } \\
\text { informacija } \\
\text { o potrebi } \\
\text { promena, toku } \\
\text { promena, } \\
\text { progresu }\end{array}$ & $\begin{array}{l}\text { Ubeđivanje } \\
\text { indoktrinacija, } \\
\text { promena } \\
\text { stavova }\end{array}$ & $\begin{array}{c}\text { Prinuda, } \\
\text { kooptacija, } \\
\text { manipulacija, } \\
\text { kompromis }\end{array}$ \\
\hline Vreme & $\begin{array}{l}\text { Traži mnogo } \\
\text { vremena, mada } \\
\text { može da varira }\end{array}$ & $\begin{array}{c}\text { Traži malo } \\
\text { vremena, } \\
\text { mada može da } \\
\text { varira }\end{array}$ & $\begin{array}{c}\text { Traži mnogo } \\
\text { vremena }\end{array}$ & $\begin{array}{l}\text { Traži malo } \\
\text { vremena }\end{array}$ \\
\hline $\begin{array}{c}\text { Svest o potrebi } \\
\text { promena }\end{array}$ & Postoji & Ne postoji & Ne postoji & Ne postoji \\
\hline $\begin{array}{l}\text { Posvećenost } \\
\text { promenama }\end{array}$ & Postoji & Postoji & Ne postoji & Ne postoji \\
\hline Širina promena & Široke promene & $\begin{array}{l}\text { Široke i uske } \\
\text { promene }\end{array}$ & Šroke promene & Uske promene \\
\hline $\begin{array}{l}\text { Dubina } \\
\text { promena }\end{array}$ & $\begin{array}{l}\text { Duboke } \\
\text { promene }\end{array}$ & $\begin{array}{c}\text { Duboke i plitke } \\
\text { promene }\end{array}$ & $\begin{array}{l}\text { Duboke } \\
\text { promene }\end{array}$ & Plitke promene \\
\hline Agent promena & $\begin{array}{c}\text { Raspolaže } \\
\text { znanjem } \\
\text { i resursima }\end{array}$ & $\begin{array}{l}\text { Raspolaže } \\
\text { znanjem i } \\
\text { resursima }\end{array}$ & $\begin{array}{c}\text { Raspolaže } \\
\text { liderskim } \\
\text { sposobnostima }\end{array}$ & $\begin{array}{l}\text { Agent mora da } \\
\text { raspolaže moći }\end{array}$ \\
\hline
\end{tabular}

Slika 5 - Strategije savladavanja otpora promenama ${ }^{17}$

Svaka organizacija mora da se menja kako kontinualno tako i diskontinualno. Ona prolazi kroz svakodnevne, parcijalne promene ali, često, njihov oblik i intenzitet nisu dovoljni da održe korak sa okruženjem. Zbog toga se stvara jaz između organizacije i okruženja, koji uzrokuje pad performansi i krizu čime se podstiču diskontinualne promene: sveobuhvatne, radikalne i intenzivne.

$\mathrm{Na}$ izbor između kontinualnih i diskontinualnih promena utiče dimenzija izbegavanje neizvesnosti. Kontinualne promene podrazumevaju nizak stepen izbegavanja neizvesnosti u nacionalnoj kulturi jer su to parcijalne ali i svakodnevne promene. Može se očekivati da samo kulture sa niskim izbegavanjem neizvesnosti prihvate ove pretpostavke. U kulturama sa visokim izbegavanjem neizvesnosti članovi organizacije nisu spremni da prihvate svakodnevne i česte promene jer preferiraju stabilnost što znači da su sklonije diskontinualnim promenama. Deluje paradoksalno da kulture sa visokim stepenom izbegavanja neizvesnosti primenjuju radikalne, revolutivne i sveobuhvatne promene koje unose daleko veći stepen neizvesnosti nego kontinualne ali objašnjenje je ipak razumljivo. Članovi organizacije će odlagati promene dok je god to moguće, ali kada više ne bude moglo, moraće da primene radikalne promene. Mnogo im je prihvatljivije da se ređe i kraće suočavaju sa visokom neizvesnošću nego sa kraćom ali neprekidnom.

\footnotetext{
${ }^{17}$ http://www.ekof.bg.ac.rs/
} 
Na izbor između ove dve promene, utiče još jedna dimenzija a to je distanca moći. Izvođenje kontinualnih promena moguće je jedino u uslovima niske distance moći zbog toga što su ove promene veoma brojne, lokalnog značaja i unose relativno mali stepen noviteta. Njihovo iniciranje treba da bude u autoritetu nižih menadžera, što znači da autoritet u organizaciji treba da je ravnomerno raspoređen na hijerarhijske nivoe a organizacija treba biti decentralizovana. Sa druge strane, radikalne mere zahtevaju snažnog lidera koji u proces promena unosi veliku moć što je apsolutna odlika nacionalnih kultura sa visokom distancom moći.

\section{Zaključak}

Nacionalna kultura opredeljuje i individualne vrednosti i ponašanje pojedinca, ali i vrednosti organizacione kulture i ponašanje celokupnih organizacija. Poznavanje uticaja nacionalne kulture na organizacione promene važno je zbog primene poznatih znanja, iskustava i naučenih lekcija u sprovođenju promena koje nam odgovaraju, ali isto tako i u uspešnom suprotstavljanju „spoljnjem nametanju“ promena koje nisu u našem nacionalnom interesu. ${ }^{18}$ Nacionalnu kulturu u Srbiji karakteriše visoka distanca moći, visoko izbegavanje neizvesnosti, visok stepen kolektivizma i dominantne ženske vrednosti (raspodela uloga između rodova). Navedene karakteristike su u suprotnosti sa karakteristikama nacionalne kulture zapadnih zemalja koje predstavljaju „ideal“ kojem Srbija teži na svom putu ka EU.

Treba biti mudar u čuvanju i razvoju svoje kulture i oprezan u promenama nacionalne kulture uopšte ${ }^{19}$ i kulture pojedinih organizacija i ne zaboraviti da je u sklopu opšteg napada na našu kulturu prvo napadnuta naša istorija. ${ }^{20} \mathrm{Ne}$ smemo izgubiti iz vida da je u vremenu u kome živimo sposobnost laganja i samozavaravanja postala faktor razvića kulture, nažalost vodeći faktor, što nije dobro ${ }^{21}$ jer dovodi do kaleidoskopskog ${ }^{22}$ poimanja sveta. Rezultat toga jeste naš život „po tuđoj koncepciji“ - pomoću nametnutih znanja o ekonomiji pljačkaju se naša bogatstva od strane ekonomskih osvajača, a mi živimo loše.

\footnotetext{
${ }^{18}$ Savremeni rat se vodi u sferi fizičke, mentalne i moralne dimenzije. Masovna primena obmana i manipulacija, napad na emocije i razum, forsiranje empirizma i gušenja duhovnosti i nametanje ideologija za lično posmatranje i razumevanje i posmatranje i razumevanje okruženja. Naučno je dokazano da su narodi koji imaju razvijenu mitsku samosvest najnepodobniii za manipulacije i na nijma propagandni mehanizmi i novostvoreni lažni mitovi imaju najmanji učinak. Najmoćnija propagandna mašinerija u istoriji četvrt veka nam ispira svest i nastoji da podrije naše kolektivno podsvesno. Učinak je sasvim skroman. Neophodno je, planski i organizovano, raditi na sprečavanju duhovnog i mentalnog genocida koji se nad našim narodom planski sprovodi kroz medije i masovnu kulturu.

${ }^{19} \mathrm{U}$ stvaranju uslova za to vaspitanje i obrazovanje imaju jako važan i veliki uticaj, posebno obrazovanje kadra za sektore bezbednost i odbrana.

20 „Nama je falsifikovana istorija nanela više štete i poraza od svih ratova! Poražavajuća je činjenica da narod kao Srbi koji je od vajkada u vrtlogu svetske istorije, narod koji je morao kroz vekove da vodi tolike odbrambene ratove, tako malo uradio da svoju istoriju istraži kako treba, prikupi sve podatke i publikuje ih, napravi muzej kakav dolikuje jednom tako starom narodu bogate istorije. Umesto toga dozvolili smo falsifikatorima "zapadne škole" da nas lažu i prekrajaju kao da smo kamenčić pored puta kojeg šutira svaki putnik“.

${ }^{21}$ Sposobnost laganja je sposobnost narušavanja kod drugih ljudi da ispravno odražavaju objektivnu realnost. To je izopačavanje ili rušenje tuđe lične mere. Laganje je kao faktor postalo deo globalnog istorijskog procesa... A istorijski proces je proces razvića kulture u globalnom evolucionom procesu razvića biosfere. A ako je cela kultura lažna ona ima svoj negativan uticaj na razviće biosfere planete zemlje. I to je dovelo do globalne ekološke krize i svih drugih kriza. Globalna sistemska kriza: Kriza je u svemu, a faktor koji je doveo do toga je laž.

${ }_{22}$ Naša nauka se zasniva na kaleidoskopskom shvatanju sveta ... sve je slučajno, okolo je haos. Ako fizičke hemijske procese prenesemo u socijalnu sferu čoveka lišavamo svesti... Naše obrazovanje formira kod ljudi „kaleidoskopski idiotizam“ i stvara ljude koji ne mogu znanje povezati u jedinstvenu celinu.
} 
Srbima su planski uništavali ${ }^{23}$ istorijske zapise ${ }^{24}$ kako bi ih držali u neznanju i lakše vladali njima. Uništi jednom narodu istoriju, uništio si ga kao narod. Srećom istina se ne može sakrivati zauvek, kad tad ispliva na površinu u punom sjaju. Kod donošenja odluka o promenama u nacionalnoj kulturi i krupnim organizacionim promenama treba pratiti i ključne vektore vremena, a ne prolazne nosioce određenih uloga, oni nisu donosioci odluka već glasnogovornici i manekeni globalnih trendova. Epohalni vektor vremena u kome živimo teži uprosečavanju ljudske svesti. Nacionalna društvena elita [16] treba učiniti pokušaj da se trznemo i uradimo nešto što će smanjiti trend dezintelektualizacije javnog života u Srbiji. Nagle promene organizacione kulture nisu poželjne, nepovoljno deluju na ljude i zasnivaju se na „reprogramiranju ljudi“ što nije u nacionalnom interesu.

Neadekvatno uvođenje novih vrednosti u nacionalnu kulturu i upravljanje promenama u organizacionim kulturama preduzeća u Srbiji može dovesti do kontradiktornih smerni$\mathrm{ca}^{25} \mathrm{u}$ organizacionom i individualnom upravljanju organizacionim promenama, do sukoba i otpora, a time i do njihovog sporog odvijanja pa i neuspeha. Nacionalna kultura ima snažan uticaj na organizacionu kulturu preduzeća i može da predstavlja ograničenje organizacionoj kulturi i praksi menadžmenta. Interes za razumevanjem nacionalne i organizacione kulture raste usled globalizacije, pojačane međunarodne kooperacije i integracije i ulaza multinacionalnih kompanija (korporacija) na naše tržište, jačanja zavisnosti među nacijama i izražene potrebe za postizanjem konkurentnosti na tržištu. Vrlo je važno razumeti uticaj nacionalne kulture na organizacione promene, vrste i proces organizacionih promena kako bi se adekvatno postupalo u istima i obezbedilo usklađeno delovanje i homogeno postupanje svih steikholdera. [15]

Kulturne vrednosti su često iskazane u misiji i viziji organizacije. ${ }^{26}$ Kultura ima snažan uticaj na ponašanje zbog toga što je zajednička za celu organizaciju i deluje, a da se o njoj ne govori, čak i ne razmišlja. Kultura se odražava u politici koju zagovara menadžment i aktivnostima koje se sprovode u organizaciji. Stoga, organizacije koje veruju u principe promena ispunjavaju prvi preduslov za njihovo uspešno sprovođenje. Sa druge strane aktivnosti pokreću promene kulture. Prema tome, ukoliko se praksa promena rutinski primenjuje unutar organizacije ljudstvo počinje da veruje u principe promena i kulturne promene počinju.

Organizaciona kultura je duboko ukorenjena u svakoj organizaciji, ona se delimično razvija kao odgovor na stimulaciju koja se doživljava i koja je zajednička za članove organizacije. Promene u organizaciji obezbeđuju njenu kompatibilnost sa zahtevima okruženja. Ona nije sama sebi cilj, već sredstvo prilagođavanja novim uslovima eksternog ili internog okru-

\footnotetext{
${ }^{23}$ Određenim centrima moći smetamo zbog otpora porobljavanju i zbog našeg iskonskog osećanja pravde, koji nosimo u genima i zbog čega smo jedini narod na svetu koji, za razliku od njih koji ratuju uvek za zemaljsko carstvo, spreman na žrtve za carstvo nebesko.

${ }^{24}$ Za vreme Prvog i Drugog svetskog rata iz Srbije je odneto oko 40 železničkih vagona arhivske građe. Nemački bombarderi su 6. aprila 1941. namerno bombardovali nacionalnu biblioteku u Beogradu, gde je uništen ceo fond od 350.000 knjiga, uključujući i srednjovekovne spise neprocenjive vrednosti!

${ }^{25}$ Tako na primer od pojedinaca se očekuje da se prilagode novim „boljim“ vrednostima prihvatajući celo životno obrazovanje i stalno ulaganje u sebe kroz proces podizanja vlastitih kompetencija, a s druge strane se savetuje oprez u odnosu na očekivanja od organizacionih promena zbog otpora promenama i niza neželjenih efekata koji prate organizacione promene.

${ }^{26}$ Na primer, nije neuobičajeno da u misiji i viziji organizacije naiđemo na iskaze kao što je „Stalno ćemo činiti napore da podignemo nivo kvaliteta svih naših proizvoda i usluga“ ili „Timski rad je osnova našeg zajedničkog uspeha“.
} 
Upravljanje sistemima

ženja, te se može reći da važi pravilo „sve dok je moguće ostvariti postavljene ciljeve bez izmena u organizaciji, promene treba izbegavati“. Upravljanje promenama je novi koncept u savremenom menadžmentu koji respektuje činjenicu da su brze promene specifična oznaka vremena u kome živimo i da preduzeće ne može efikasno da posluje i da se razvija, ako ne ide u korak sa promenama i ako ih ne koristi. Osnov uspešnog upravljanja preduzećem, jeste brzo reagovanje na promene i prilagođavanje promenama. Danas nema realnih mogućnosti da se posluje i upravlja bez promena. Koncept upravljanja promenama tako postaje današnji i sutrašnji upravljački koncept, koji se koristi u svetu, a treba se koristiti i kod nas.

Upravljanje promenama zahteva od zaposlenih u organizaciji da usvoje nova znanja, steknu veštine i sposobnosti, koriguju određene stavove, menjaju svoje radne navike, vrednosti i stavove. Ovo uključuje promene u ljudima i kod uprave preduzeća i kod zaposlenih, promene njihovih sposobnosti, motivacije, ponašanja i delotvornosti na radu. Isto tako uključuje i promene u organizacionoj kulturi - promene vrednosti, ustaljenih običaja, informacionih odnosa, uticaja, promene stila upravljanja. Kako je to čitav proces korenitih promena - ne odvija se sam po sebi: potrebno je i učenje, i vreme, napor, upornost, sposobnost, odanost i predanost poslu koji se obavlja. Organizacione promene se vrše, pravovremeno i evolutivno, radi prilagođavanja zahtevima okruženja (mogućnost poboljšanja funkcionisanja, opasnost od konkurencije), a revolucionarno kad je već kasno i kad nastupi stanje loše po organizaciju. Saznanja o uzrocima i konsekvencama razlika između menadžment prakse u različitim nacionalnim kulturama dovela su do razvoja nove oblasti menadžmenta - „oblast inter - kulturalnog menadžmenta (cross - cultural management) ${ }^{\text {«27 }}$, pa istu treba više izučavati i na našim visokim školama i fakultetima.

\section{Literatura}

[1] Schwartz, S.H. (2008).Cultural Value Orientations: Nature and Implications of National Differences.Jerusalem:Israel Science Foundation

[2] Hofstede, G. (1983).National cultures revisited Behavior Science Research, 4, 285-305.

[3] Hofstede, G. (2001). Culture's Consequences. Comparing Values, Behaviors, Institutions, and Organizations Across Nations. Thousand Oaks, CA: Sage.

[4] Janićijević, N. D. (2003). Uticaj nacionalne kulture na organizacionu strukturu preduzeća u Srbiji. Ekonomski anali, 44(156), 45-66.

[5] Andrejić, Marko., Čabarkapa Obrad. Timski rad u vojnim organizacionim sistemima /M. Andrejić, O. Čabarkapa// U: VOJNO DELO.- Beograd.- God. 53., broj 3 (2001):str. 83 - 108.

[6] Andrejić, M., Milenkov, M, Sokolović, V. Koncept razvoja službi logistike /Marko Andrejić, Marjan, Milenkov, Vlada Sokolović // U: VOJNOTEHNIČKI GLASNIK - Beograd, Godina 58., broj 1 (2010): strana 37-62.

[7] LJubojević, S., Andrejić, M., Dragović, N. (2013) „Prilog unapređenju menadžmenta u logistici odbrane”, // U: VOJNOTEHNIČKI GLASNIK - Beograd, Godina 61., broj 4 (2013): strana 80-120.

[8] Marko D. Andrejić, Ivana M. Andrejić, Slaviša N. Arsić, Srđan D. LJubojević. Prilog unapređenju rada i upravljanja u Vojnoj akademiji i na Univerzitetu odbrane // U: VOJNOTEHNIČKI GLASNIK - Beograd, Godina 61., broj 2 (2015): strana 136-150. DOI: 10 5937/vojtehg62-4091

\footnotetext{
${ }^{27}$ Interesovanje za uticaj nacionalne kulture i inter - kulturalni menadžment je naglo poraslo sa intenziviranjem globalizacije i povećanjem kooperacije i integracije među nacijama, u različitim oblastima života i rada.
} 
[9] Trandafilović, S., Đorđević, Z., Dragović, N., Andrejić, M., SISTEM ZARADA I MOTIVACIJA PROFESIONALNIH VOJNIH LICA U FUNKCIJI RAZVOJA LJUDSKIH RESURSA U MINISTARSTVU ODBRANE I VOJSCI SRBIJE, Zbornik radova sa 19. DQM Međunarodna konferencija UPRAVLJANJE KVALITETOM I POUZDANOŠĆU ICDQM-2016, strana 652-658, izdavač Istraživački centar za upravljanje kvalitetom i pouzdanošću - DQM, Prijevor, 2016.

[10] Marko Andrejić, Marjan Milenkov. PRISTUP STVARANJU OFICIRA moderne logistike, I Marko D. Andrejić, Marjan Milenkov // U: VOJNO DELO.- Beograd.- God. 67, broj 7 (2016.): str. 293 - 300. DOI: 10.5937/vojdelo1504293A

[11] Mirković, B. Socio-psihološki činioci odgovornog organizacionog ponašanja. Doktorska disertacija, Filozofski fakultet - Beograd, 2016.

[12] Marko Andrejić, Marjan Milenkov. PRILOG UNAPREĐENJU PROMIŠLJANJA O PROMENAMA U LOGISTICI ODBRANE, Zbornik radova sa 20. DQM Međunarodna konferencija UPRAVLJANJE KVALITETOM I POUZDANOŠĆU ICDQM-2017, strana 37-62, izdavač Istraživački centar za upravljanje kvalitetom i pouzdanošću - DQM, Prijevor, 2017.

[13] Slobodan Panić, Marko Andrejić, Marjan Milenkov, Simona Andrejić i Marijan Mirčevski. Inovacija menadžmenta u funkciji razvoja; DOI: 10.5937/vojdelo1802394P, strana 394-413

[14] Đurđijana llić, Marko D Andrejić i Miljojko Janošević. Prilog unapređenju komunikacije i poslovanja u logističkim poslovima sistema; DOI: 10.5937/vojdelo1707424I; strana 424-436.

[15] Marko D. Andrejić, Nenko Brkljač, Marjan A. Milenkov. PRILOG UNAPREĐENJU PROMIŠLJANJA O MOGUĆIM POBOLJŠANJIMA NA UNIVERZITETU ODBRANE, Vojno delo 6/2018, strana 237-263; DOI: 10.5937/vojdelo1806237A

[16] Marko Andrejić, Slobodan Panić, Đurđijana llić. ULOGA I DELOVANJE ELITE U OSLOBAĐANJU I USMERAVANJU DRUŠTVENE ENERGIJE; Vojno delo 5/2018, strana 334-355; DOI: 10.5937/vojdelo1805334A 